\title{
THE USAGE OF NATURAL FERTILIZERS - A PRACTICE THAT FAVORS THE ECOLOGICAL AGRICULTURE DEVELOPMENT IN ROMANIA
}

\section{UTILIZAREA ÎNGRĂŞĂMINTELOR NATURALE - O PRACTICĂ CE FAVORIZEAZĂ DEZVOLTAREA AGRICULTURII ECOLOGICE ÎN ROMÂNIA}



e-mail: anaandreeaghiurca@yahoo.com

\begin{abstract}
Natural fertilizers were used in agriculture since ancient times and are still the best method of soil fertilization. Traditional agriculture, practiced in rural areas of Romania, contributes to the maintenance of soils fertilization ecological practices. Our research shows the evolution of the quantity of natural fertilizers used in the past 20 years at the national level and at the level of Neamt County captures the evolution over the seven years of natural fertilizers areas. In the analyzed period, the quantity of natural fertilizers on agricultural land is growing, but fertilized land record low values, showing that it has increased the average quantity of natural fertilizers per hectare.
\end{abstract}

Key words: organic fertilizer, ecological agriculture, rural space.

Rezumat. Îngrăşămintele naturale au fost utilizate în agricultură din cele mai vechi timpuri şi reprezintă încă cea mai bună metodă de fertilizare a solului. Agricultura tradițională, practicată în spațiile rurale din România, contribuie la menținerea practicilor ecologice de fertilizare a solurilor. Cercetarea noastră evidențiază evoluția cantității de ingrăşăminte naturale utilizate in ultimii 20 de ani la nivel național, iar la nivelul județului Neamț surprinde evoluția pe parcursul a şapte ani a suprafețelor fertilizate cu ingrăşăminte naturale. În perioada analizată, cantitatea de ingrăşăminte naturale aplicată pe terenurile agricole este în creştere, însă suprafețele fertilizate înregistrează valori scăzute, ceea ce demonstrează că a crescut cantitatea medie de ingrăşăminte naturale la hectar.

Cuvinte cheie: îngrăşământ natural, agricultură ecologică, spațiu rural.

\section{INTRODUCTION}

Organic farming is a practice that encourages the sustainable production, with a low impact on the quality of environmental factors and attempts to replace the model of intensive agricultural production. Organic production is focuses on developing sustainable agricultural systems, which protect both, the environment and consumers. Thus, organic farming represents a solution to protect soil resources by using natural fertilizers

\footnotetext{
1 “Alexandru Ioan Cuza” University of Iasi, Romania
} 
(Mäder et al., 2002). Organic fertilizer represents "the fertilizer made from different natural products with organic origin through a simple training or through composting" (Research Institute for Soil Science and Agrochemistry, 2002). A proper application of natural fertilizers improves soil quality and maintains potential by introducing the nutrients.

Using natural fertilizers on agricultural soils, in significant amounts in Romania, makes our country to hold a high potential for practicing sustainable agriculture. However, one aspect that should be taken into account is the dose of fertilizer applying on farmland, which must not exceed the concentrations that could lead to an impairment of the soil quality. Soil pollution by nitrates can be a direct consequence of improper usage of natural fertilizers by farmers, and this happens frequently in rural areas in Romania, due to the lack of environmental education.

The idea of development the organic farming practices appeared in Europe as an alternative, that follow the principles of sustainable development by removing the aggressive practices of intensive agriculture, mechanized (Roman et al., 2008). In addition to environmental protection, it has been taken into account the fact that sustainable agriculture contributes to improving the quality of food and is reflecting on human health.

\section{MATERIAL AND METHOD}

This research represents the correlation between the usage of organic fertilizers and organic farming by analyzing the European space, in general, and local and national territory, in particular. At the European level we analyzed the evolution in time of land areas used for organic farming, with statistical data for the period 2005-2010, made available by the Research Institute of Organic Agriculture (FiBL) from Switzerland. This was accomplished in the Philcarto program, a cartographical material based on multivariate analysis and hierarchical ascending classification method. The European States have been divided into five typological classes, each class referring to the European average.

The evolution of the amount of natural fertilizers used at national level in the past 20 years, and at local level in the past seven years is highlighted by graphs made using statistics provided by National Institute of Statistics and the Environmental Protection Agency Neamt.. Analysis of the amount of fertilizer used in European and national level is achieved through graphs.

Regarding the organic agriculture development in Romania, with data provided by the Ministry of Agriculture and Rural Development, at the level of 2011, we made illustrative graphics and cartographic materials. From the data available for Neamt County level, we made a number of correlations about practicing organic farming in the area and the ecological education level of farmers.

Thus, on the one hand, we have been highlighted in time the evolution of the natural fertilizers quantity used and the area that it was submitted, and on the other hand, we have been correlated the vulnerable areas to nitrates pollution with operators registered in organic farming, in 2011. 


\section{RESULTS AND DISCUSSIONS}

From the total of fertilizers used on cropland in Romania, natural fertilizers are used in quantities much higher than chemical fertilizers. The chemical fertilizers were used in much larger quantities in the early 1990s, especially on areas owned by the state. (fig. 1). It can be seen that during the past 20 years, the quantity of natural fertilizers used has remained relatively constant. The share of the natural fertilizers used by private property is majority; therefore farmers prefer natural fertilizers against the chemical manures (fig. 2).

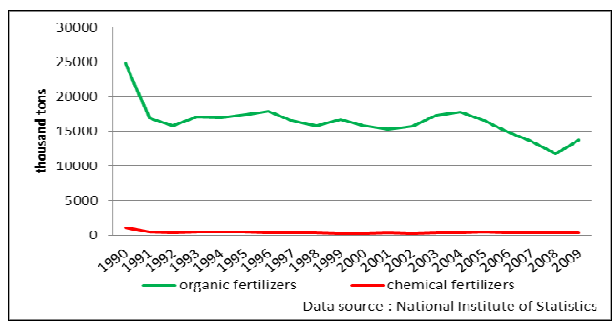

Fig. 1 - The quantity of natural and chemical fertilizers used in Romania

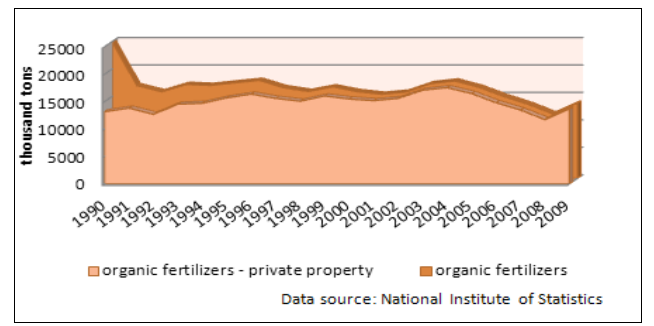

Fig. 2 - The quantity of natural fertilizers used in Romania

According to data provided by Eurostat, regarding the consumption of chemical fertilizers at European level, Romania uses a smaller amount of such fertilizers, so the soil resources available to agriculture can be used in organic agricultural production (fig. 3).

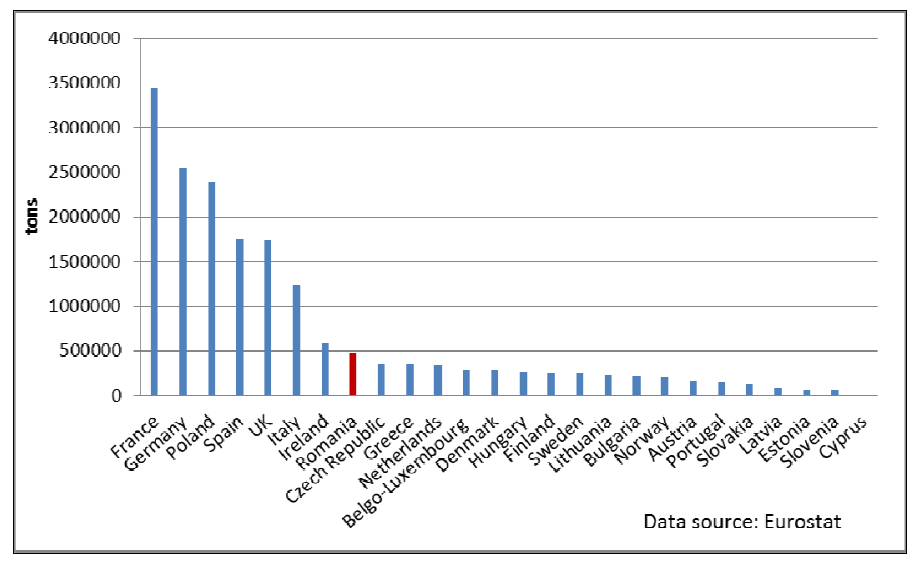

Fig. 3 - Consumption of chemical fertilizers in European countries, 2009

In Europe, the share of land used in organic farming, from the total agricultural land, has increased in the past five years, some countries giving particular attention to these practices. Following the multivariate analysis, the European States are included into five typological classes, depending on the deviations to the European average. Thus, the states represented in green and blue 
shades (Italy, Austria, Switzerland, Spain, Portugal, Sweden, Norway, Finland etc.) have large areas of land used in organic farming (over $10 \%$ of the total agricultural area) which are growing. The states represented in yellow and pink shades (Belgium, France, Netherlands, Poland, Romania, Ukraine etc.) have smaller areas introduced in organic farming (less than $5 \%$ of the total agricultural area), but in steadily growing, thus, the potential development of these practices is high. The largest deviation compared to the European average is represented by states in red shades (Iceland, Russia, Bulgaria etc.), where organic farming is very poorly developed, and future prospects are not encouraging.

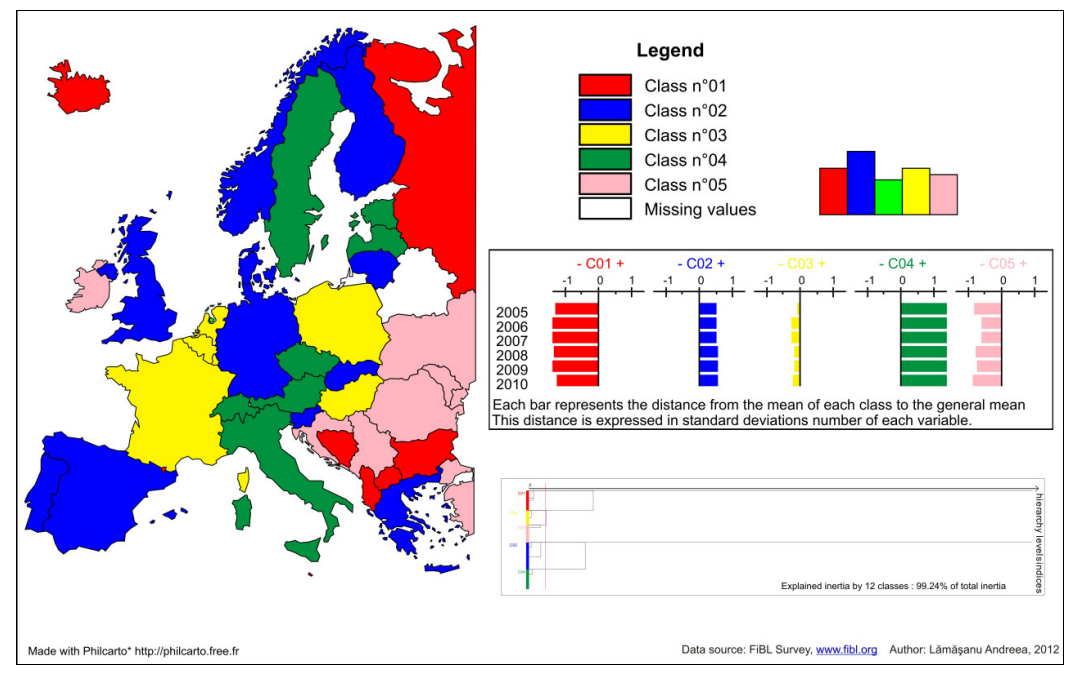

Fig. 4 - The share of land used in organic farming of the total cropland at European level, 2005-2010

Organic fertilizers are essential for practicing organic farming, and Romania understood that it presents a high potential. Thus, an increasing number of Romanian farmers, supported and encouraged by the European Union have started using ecological techniques. This fact is evidenced by the number of registered organic operators, which has grown in recent years, the highest value being recorded in 2011 (fig. 5).

Development of ecological agriculture in Romania, in recent years is due to the subsidies granted by the European Union, which have encouraged farmers to adopt new practices for processing cropland. Thus, at the level of 2011 it has been registered at the Ministry of Agriculture and Rural Development over 10000 operators in organic farming, the Suceava and Bistrița-Năsăud County being the most well represented (fig. 6). 




Fig. 5 - The number of registered organic operators at national level, 2006-2011



Fig. 6 - The number of operators registered on counties in organic farming, 2011

The same trend, as at the national level, was observed in Neamț County, so natural fertilizers consumption increased, especially in recent years. The surfaces that were used natural fertilizers is in a slight decrease in the period 2003-2008, in contrast, the average quantity applied per hectare is increased, which could lead to a higher level of nitrates in soil (fig. 7).

According to data provided by the Environmental Protection Agency Neamț, in 2009, we have been identified a number of 40 vulnerable commune to nitrate pollution. Inappropriate agricultural practices, represented by the usage of high quantities of natural fertilizers, have led to soil degradation in extended areas (fig. 8).

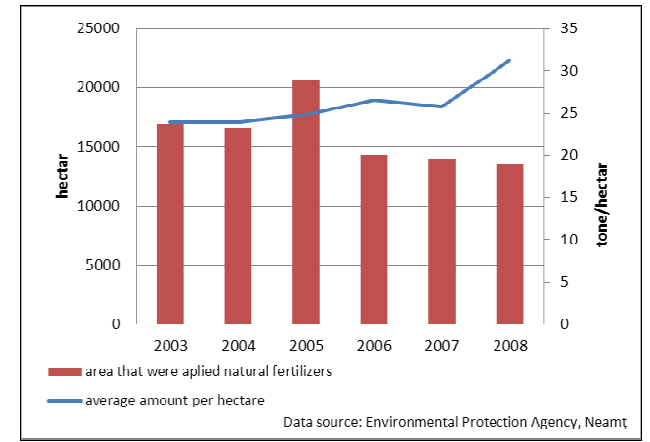

Fig. 7 - Area where natural fertilizers were applied and the average quantity per hectares (in Neamț County)

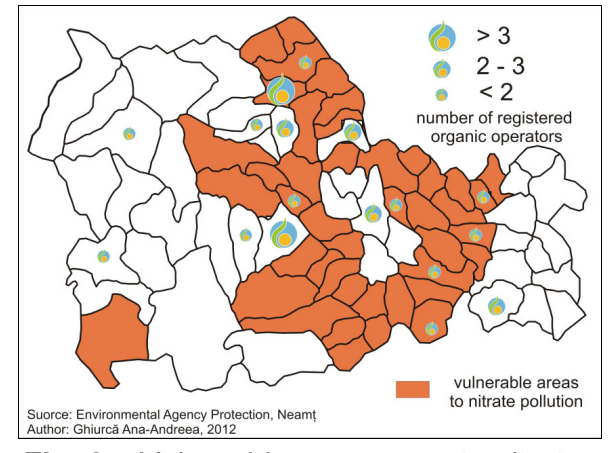

Fig. 8 - Vulnerable communes to nitrate pollution and the number of registered organic operators in Neamt, County, 2011

Correlation between vulnerable areas to nitrate pollution and the distribution of registered organic operators in the organic farming shows that a part of them operate on sensitive land, indicating that the practices are not friendly with the environment, because they are used for work polluted soils. 


\section{CONCLUSIONS}

1. The major role of natural fertilizers application on cropland is reflected in the environmental education level of farmers, who are increasingly interested in organic farming and sustainable exploitation of natural resources in rural areas.

2. This dynamic sector is increasing in Romania, improving the environmental conditions and promoting the consumption of organic products, but in the same time supports the restoration of rural areas by creating new jobs and opportunities.

3. Practicing organic farming is encouraged at European level, but the effective implementation is not an easy process because, as can be seen in the Neamț County, some croplands are already vulnerable to pollution by nitrates.

Acknowledgements: This work was supported by the European Social Fund in Romania, under the responsibility of the Managing Authority for the Sectorial Operational Program for Human Resources Development 2007-2013 [grant POSDRU/107/1.5/S/78342].

\section{REFERENCES}

1. Roman V. G., Ion V., Epure L. I., Toader M., Truța A. M., Duşa E., Băşa A. G., 2008 Principii şi practici de bază în agricultura ecologică, Editura Alpha Mdn, Buzău, p. 10.

2. Mäder P., Fliessbach A., Dubois D., Gunst L., Fried P., Niggli U., 2002 - Soil fertility and biodiversity in organic farming. Science Magazine 31.06.2002, vol. 296, p. 1694-1697.

3. ***, 2009 - Anuarul Statistic al județului Neamț, p.129.

4. ${ }^{* * *}, 2009$ - Raport privind starea mediului în județul Neamț. Agenția de Protecția Mediului Neamt, p 82.

5. ***, 2010 - Raport privind starea mediului în județul Neamț. Agenția de Protecția Mediului Neamt, p. 80.

6. ${ }^{* * *}$, European Comission Eurostat (accesat în martie 2012).

7. ${ }^{* *}$, www.fibl.org (accesat în martie 2012). 